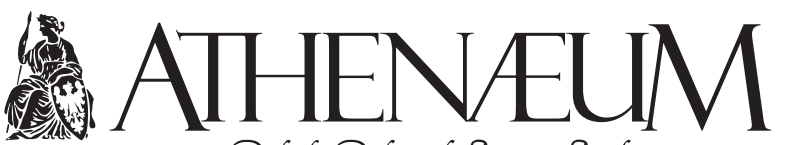

Polish Political Science Studies

Polskie Studia Politologiczne

vol. 60/2018, pp. 142-159

DOI: 10.15804/athena.2018.60.09

www.athenaeum.umk.pl

ISSN 1505-2192

(c) $(1) \odot$

\title{
GERMAN CULTURAL POLICY \\ IN THE REICH PROVINCE OF DANZIG-WEST PRUSSIA: A SHORT CHARACTERISTIC
}

\author{
NIEMIECKA POLITYKA KULTURALNA \\ W OKRĘGU RZESZY GDAŃSK-PRUSY ZACHODNIE: \\ KRÓTKA CHARAKTERYSTYKA
}

Sylwia Grochowina* •()

\begin{abstract}
- ABSTRACT
An important element of the ethnic and racial policy pursued by the German occupant in the Reich Province of Danzig-West Prussia was cultural policy (Kulturpolitik). Admittedly, since the first days of occupation the German authorities attached great importance to matters of culture however, in the Nazi reality there was no cultural policy understood as encouragement and support offered by state authorities for independent, artistic creativity in its varied forms. The Nazis "controlled" culture, which played an important role in the process of creating a new reality in the annexed Polish territories. In the present paper, the author discusses selected issues illustrating the organization and forms of German cultural life in the Danzig-West Germany Province of the Reich. In outlining the German cultural policy, two main aspects were taken into account: culture as just another component of the broader Ger-
\end{abstract}

Ważnym filarem polityki narodowościowej realizowanej przez okupanta niemieckiego w Okręgu Rzeszy Gdańsk-Prusy Zachodnie była polityka kulturalna (Kulturpolitik). Wprawdzie już od pierwszych dni okupacji władze niemieckie przykładały ogromną wagę do spraw kultury, ale w realiach nazistowskich nie istniała polityka kulturalna rozumiana jako inicjowanie i wspieranie przez władze państwowe niezależnej, szeroko pojętej twórczości artystycznej. Naziści „sterowali” kulturą, która odgrywała ważną rolę w procesie kreowania nowej rzeczywistości na zaanektowanych polskich obszarach. W niniejszym artykule omówiłam wybrane kwestie, które ilustrują organizację oraz formy niemieckiego życia kulturalnego w Okręgu Rzeszy Gdańsk-Prusy Zachodnie. Kreśląc obraz niemieckiej polityki kulturalnej, starałam się uwzględnić dwa zasadnicze aspekty, tj. kulturę jako element

\footnotetext{
* Nicolaus Copernicus University in Toruń, Faculty of History.
} 
man nationalistic and ethnic policy, as well as its role as an integral part of social reality.

Keywords: World War II, Nazism, German occupation 1939-1945, Reich Province of DanzigWest Prussia, Polish territories incorporated into the Third Reich, Nazi cultural policy składowy niemieckiej polityki narodowościowej oraz integralną część społecznej rzeczywistości.

Słowa kluczowe: II wojna światowa, nazizm, okupacja niemiecka 1939-1945, Okręg Rzeszy Gdańsk-Prusy Zachodnie, ziemie polskie wcielone do Trzeciej Rzeszy, nazistowska polityka kulturalna

On September 1, 1939, without a prior declaration of war, German troops launched an armed attack on Poland, and within several weeks occupied almost half of the Republic's territory, i.e., 188,705 km² (in November 1939, $752 \mathrm{~km} 2$ were handed over to Slovakia). After the period of military management of the occupied Polish territories that lasted until October 25, 1939 (inclusive), civilian administration was introduced. As concerns the western, northern and south-western territories of the pre-war Polish state, the principles of administration were regulated by the Führer's decree of October 8, 1939 concerning the organization and administration of the Eastern Territories, in force since October 26,1939 . On its basis, the Polish pre-war voivodeships of Silesia, Pomerania, and Poznań, as well as parts of the voivodeships of Łódź, Kielce, Kraków (western portion), Warsaw (northern part) and finally the Suwałki district in the Białystok voivodeship, were incorporated into the Third Reich. In these annexed Polish territories, the German occupants formed new administrative units - one of them was the Reich Province of West Prussia, Reichsgau Westpreussen, whose name was changed on November 2, 1939 to Reichsgau Danzig-Westpreussen (Danzig-West Prussia Province). In total, its surface area was $26,056 \mathrm{~km}^{2}$ (of which 21,223 $\mathrm{km}^{2}$ were formerly Polish lands). It encompassed the Free City of Gdańsk (Danzig), six districts from the German East Prussia Province [Elbing (now Elbląg) - urban, Elbing - rural, Marienberger (now Kwidzyn), Marienburg (Malbork), Rosenberg (now Susz) and Stuhm (now Sztum)] and most of the pre-war Pomeranian voivodeship (without the poviats or districts of Inowrocław, Włocławek, Szubin and Nieszawa), as well as a small portion of the Warsaw voivodeship. The Province was divided into three boroughs: Bydgoszcz (Regierungsbezirk Bromberg), Gdańsk (Regierungsbezirk Danzig) and Kwidzyn (Regierungsbezirk Marienwerder), each of which was managed by a Borough President (Regierungspräsident). Each borough was further divided into urban districts (Stadtkreis) headed by a mayor (Oberbürgermeister), rural districts 
(Landkreis) headed by a starost (Landrat) and smaller municipalities (Gemeinde) managed by commissioners (Amtskommissar)'.

The supreme administrative authority in the Province was held by the Reich's Governor (Reichsstatthalter), who was also the regional head of NSDAP (Gauleiter der NSDAP). In the Reichsgau Danzig-Westpreussen, this post was occupied by Albert Forster, who - faithful to Adolf Hitler's plans for Poland laid out before September 1,1939 - already in his first secret guidelines for management and administration of the German-occupied areas in Western Prussia announced the plan for their complete assimilation with the Third Reich through universal and intensive Germanization activity (Sziling, 1989, pp. 43-53).

An important component of the nationalist ethnic and racial policy pursued by A. Forster was cultural policy (Grochowina \& Kącka, 2014). Its foundations were laid out in a secret memorandum of November 25, 1939, drawn up by Dr. Erhard Wetzel and Dr. Gerhard Hecht of the NSDAP Office of Racial Policy. The document, entitled "Treatment of the Population of Formerly Polish Territories from a Racial and Political Point of View" (Die Frage der Behandlung der Bevölkerung der ehemaligen polnischen Gebiete nach rassenpolitischen Gesichtspunkten), reads, inter alia: "[...] it must be made absolutely impossible to maintain any own Polish national and cultural activity [...]. Therefore, no anchor points can be left for the Poles to pursue own national and cultural life [...]. In order to destroy all originally Polish cultural and economic life, there can be no Polish corporations, unions or associations [...]. Polish restaurants and cafes - as center points of Polish national life - should be banned. Poles are forbidden to visit German theaters, playhouses and movie theaters. Polish theaters, cinemas and other places of cultural entertainment should be closed. There will be no Polish newspapers, and no Polish books and magazines will be published. For the same reasons, Poles are not allowed to possess radio stations and gramophones" (Program narodowościowy... [1939 Racial and Ethnic Program...]). The above excerpts clearly indicate that the German occupant intended to completely cut off Poles from their native culture, an important source of national tradition. Moreover, at every opportunity, the Nazi propaganda apparatus emphasized that Poles as sub-humans were a primitive nation that did not create its own valuable culture as they did not possess any culture-creating abilities. At the same time, Polish cultural property was destroyed and plundered, and all organized forms

1 For more on administrative division of the occupied Polish territories see, inter alia: Janowicz (1951); Madajczyk (1970, pp. 64-71); Jastrzębski \& Sziling (1979, pp. 46-55). 
of Polish cultural life were liquidated. The German invaders also implemented a consistent and ruthless policy of destroying the elites of the conquered nation, i.e., the broadly defined intelligentsia, including representatives of the world of culture $^{2}$. All these activities constituted a sort of prelude to organization of a German cultural life in the territories instead, where both creators and recipients of culture belonged exclusively to the German population.

Characteristic features of German cultural policy on the Polish territories incorporated into the Third Reich, including the Danzig-West Prussia Province, were the institutionalization and centralization of culture, which has become an element of the administrative and party structures. State and party institutions and agencies were guarding proper implementation of the Nazi cultural policy, and their influence extended to all areas of cultural life. They kept tight control over the circulation of all cultural content. Already in the first weeks of occupation, a representative of the Reich Chamber of Culture (Reichskulturkammer, $\mathrm{RKK})^{3}$, i.e., a national plenipotentiary for culture (Landeskulturwalter) - in the person of Dr. August Goergens - started his work in the Province of Danzig-West Prussia. At the beginning of October 1939, in order to "restore cultural life", he asked the local administrative authorities to prepare reports on the regional state of culture (Letter of A. Goergens to the Torun City Commissar W. Kiessling, of October 7, 1939).

In the office of the Reichsgau Danzig-Westpreussen Governor, matters of culture belonged to the competences of Division III: Education, Science, Culture and Care for Community (Amt III: Erziehung, Unterricht, Kultur und Gemeinschaftspflege). As reported, on March 1, 1940 the Division's structure included three departments dealing with cultural affairs: III/5 - state curator of museums (III/5 - Staatlicher Museumspfleger), with Prof. Willi Drost as director; III/6 - libraries (III/6 - Büchereiwesen), director- Dr. Hassbargen; III/7 - and department for cinema (III/7, Filmwesen), headed by Bruno Maria Schmidt (Vorläufiger Organisationsplan, 1940). The head of entire Division III was Adalbert Boeck, with counselor of the senate Franz Schramm (Letter of A. Goergens to the Torun City Commissar W. Kiessling, of October 7, 1939), deputizing for

2 More on the extermination of Polish intelligentsia in the Danzig-West Prussia Province can be found in: Steyer (1967); Bojarska (1972); Wardzyńska (2009).

3 Reich Chamber of Culture (Reichskulturkammer, RKK) was established in a Law of September 22, 1933 (Reichskulturkammergesetz), and was headed by Joseph Goebbels. All artists had to register with the RKK, which was divided into seven departments (subdivisions) dealing with various forms of artistic expression; for more, see inter alia: Dahm (1986, pp. 53-84); Biały (1987, pp. 241-259). 
him during Boeck's active military service. Borough presidents were executors of the Governor's orders only in certain areas. In matters of culture, they did not serve as intermediaries between the Governor's Office and cultural offices (Kulturamt) in cities and districts, so in the structures of the borough offices there was no department responsible for culture. In turn, at the level of poviat (district) administration, particular matters subordinated to the mayor (urban districts) or Landrat (rural districts) were grouped together into Sections (Referate) and lower-level units on the basis of a material criterion. Cultural issues fell within the scope of competences of Section IV - Education/Culture, and a separate unit for culture functioned within its framework (Pospieszalski, 1946, pp. 12-20; Janowicz, 1951; Jastrzębski \& Sziling, 1979, pp. 53-55). In addition to state administration bodies, the NSDAP officers supervised cultural activities as well. The aforementioned function of national plenipotentiary for culture, acting on behalf of the RKK, has been linked (in a personal union) with the role of the head of the NSDAP Propaganda Office for the Province. From the end of December 1939, both posts were occupied by Wolfgang Diewerge, who in the middle of 1940 was replaced by Wilhelm Löbsack. Then, these functions were held successively by: Max Stampe from 1942, Emil Zobus from 1943 and from the end of September 1943 again by W. Diewerge (Der Danziger Vorposten (18.01.1942), 17, 5; (21.09.1943), 260, 3; (22.09.1943), 261, 3; Thorner Freiheit (20.01.1942), 16, 4; Jastrzębski \& Sziling, 1979, p. 57).

The competences of provincial state and party administration authorities in the field of cultural policy have not been clearly defined, which in practice often led to conflicts between them (Grochowina, 2013, pp. 114-116). The Governor and Gauleiter of the Reich Province of Danzig-West Prussia, A. Forster, attempted to eliminate or at least limit them, and initiated the creation of a provincial cultural organization called Kulturwerk Deutsches Ordensland (Cultural Works of the German Lands of the Teutonic Order). It operated under his personal protectorate and was supposed to "unite cultural forces in the Province and fill it with German culture" and "support artists and create for them such [working] conditions that they can become involved in cultural reconstruction work" (Statutes of the Kulturwerk Deutsches Ordensland Organization of August 13, 1941; Letter of the Head of the Province Propaganda Office to the President of the Gdańsk (Danzig) Borough of September 4, 1941; Grochowina, 2013, pp. 120-121).

Implementation of the cultural policy required adequate personnel resources, especially when it came to creators of culture. One's abilities were not decisive for the possibility of undertaking creative work; priority requirements were rather 
one's Aryan origin, proper political attitude and uncritical commitment to execution of tasks set out by the state and party authorities. Freedom and creative independence were irrelevant, they were contrary to the idea of a totalitarian state that controlled all spheres of citizens' lives, including culture. Both style and scope of subject matter - suitable for propaganda uses - were heavily influenced by the authorities, and censorship "protected" citizens from dissemination of cultural products deemed "harmful".

In the Reich Province Danzig-West Prussia, the artistic community was represented by the "Danzig-West Prussia Exhibition Association" (Ausstellungsgemeinschaft Danzig-Westpreussen), created in February 1941 under the direction of painter Paul Dannot (Statutes of the Ausstellungsgemeinschaft Danzig-Westpreussen Organization; Letter of the National Plenipotentiary for Culture to the Mayor of Starogard Gdański of December 10, 1941; Note on Establishment of the Organization Kulturwerk Deutsches Ordensland; Thorner Freiheit (18.02.1941), 41, 4; Diewerge, 1940, pp. 88-89). The Association mainly organized exhibitions, particularly promoting local artists. One of the major exhibitions prepared by Ausstellungsgemeinschaft Danzig-Westpreussen opened on January 15, 1944 at the City Museum in Gdańsk. It was named the "Regional Exhibition of West Prussian Painters" (Gauausstellung westpreussischer Maler) and presented more than three hundred oil paintings and watercolors painted by "the best native West Prussian artists" (Thorner Freiheit (14.01.1944), 11, 3; (17.01.1944), 13,3-4). District authorities tried to maintain contact with painters from the Reich and for this purpose they organized, among others, open-air painting meet-ups, the leitmotif of which was the regional landscape. In the summer of 1941, fourteen painters visited the Reich Province of Danzig-West Prussia at the invitation of Governor A. Forster for such open-air sessions. The result of this series of visits was an exhibition titled "Prussian Lands through the Eyes of South-German Painters" (Süddeutsche Maler sehen das Ordensland), organized by Kulturwerk Deutsches Ordensland. It opened on May 28, 1942 at the City Museum in Gdańsk and hosted over 140 works created during the open-air meet-ups (oil paintings, watercolors, drawings, lithographs). The works were later on also shown in Berlin and Munich (Der Gauring. Mitteilungsblatt des Gauringes Danzig-Westpreussen der NSDAP, 4-5/1942, pp. 6-8; Deutsche Rundschau (13.05.1941), 111, 5; (21.05.1942), 119, 6; (1.06.1942), 127, 2; Thorner Freiheit (5.01.1942), 3, 3; (30/31.05.1942), 125, 4; (1.06.1942), 126, 2).

A number of initiatives related to dissemination of German literature and, in particular, promotion of local authors were undertaken in the Danzig-West 
Prussia Province by the organization Ostdeutscher Dichterkreis (East German Poetic Society). Its ordinary members were local German writers who in their work made references to the richness of the Province's cultural traditions. Extraordinary membership was granted to private or legal persons wishing to join the organization in execution of its statutory tasks. Activity of the Ostdeutscher Dichterkreis focused mainly on organizing face-to-face meetings with authors, readings and lectures devoted to literature as well as exhibitions of books deemed "remarkable" (Statutes of the Ostdeutscher Dichterkreis Organization [not dated]; Letter of the Propaganda Office of the Danzig-West Prussia Province to the President of the Gdańsk (Danzig) Borough of September 5, 1941). A large exhibition of German literature opened, for example, on August 17, 1940, on the premises of the Torun City Hall under the heading "German Books in German Torun'" (Das deutsche Buch im deutschen Thorn) and visitors had the opportunity to see about 650 old prints from Toruńs printing houses. The exhibition lasted until September 15, and in December 1940 it was also presented in Gdańsk. Cumulatively in both cities, the exhibition was visited by over five thousand people (Thorner Freiheit (16.08.1940), 192, 3; (17/18.08.1940), 193, 3; (19.08.1940), 194, 3; (14/15.09.1940), 217, 3; (17.09.1940), 219, 3; Niedzielska, 2006, p. 669; Birecki, 2011, pp. 92-93). Another exhibition, entitled Dichtung des Ostens (Poetry of the East), was devoted to German poets from the Polish territories incorporated into the Third Reich and East Prussia. It opened in the Torun Town Hall on August 28, 1942. From among writers living in the Danzig-West Prussia Province, the works of Gottfried Graf Finckenstein, Max Halbe, Franz Lüdtke, Brunhild Lüttmann and Werner Schienemann (Thorner Freiheit (26.08.1942), 200, 3; (29/30.08.1942), 203, 3; Niedzielska, 2006, p. 669) were presented. The East German Poetic Society also participated in organizing a sort of literary meet-ups or plein-airs. Writers from the Reich visited the Province of Danzig-West Prussia for a while, in search of inspiration for new creative activities, and at the same time presented their previous literary creations. In the second half of October 1939, at the initiative of the Reich Ministry of Public Enlightenment and Propaganda, a group of ten German writers visited such cities as Bydgoszcz, Gdańsk, Gdynia, Grudziądz, Tczew, and Toruń (Der Danziger Vorposten (23.10.1939), 251, 5; (24.10.1939), 252, 5; (25.10.1939), 253, 5; (20.11.1939), 279, 6; Deutsche Rundschau (26.10.1939), 242, 3; Thorner Freiheit (23.10.1939), 29, 4). The fruit of this "literary inspection" (Orłowski, 1979, pp. 109-110) conducted under the leadership of the President of the Reich Chamber of Culture Subdivision for Literature, Hanns Johst, was the publica- 
tion entitled Dichter auf den Schlachtfeldern in Polen (Schlecht \& Riecke, 1939), affirming and justifying the German war campaign against Poland.

The Nazis, convinced of particular musicality of the "wide masses of the German nation" and the "superiority of German music" (Drewniak, 1969, pp. 168-169), paid a lot of attention to organization of musical life, distinguished by considerable diversity. In the Reich Province of Danzig-West Prussia, the musical societies Konzertring Danzig-Westpreussen (Danzig West Prussia Concert Association), Gemeinschaft für alte Musik (Early Music Society) and Arbeitskreis für zeitgenössische Musik (Association for Contemporary Music) have made great contributions to consolidating the musical circles and popularizing music among a large variety of social groups (Grochowina, 2013, pp. 233-234).

In the Reichsgau Danzig-Westpreussen, a significant contribution to the development of musical life was made by urban symphony orchestras from Bydgoszcz, Grudziądz and Torun. The first of them was the symphony orchestra in Torun (Städtisches Orchester Thorn), which commenced its activity under the direction of Otto Erich Staeger in April 1940. After Staeger's departure to The Hague, on July 1, 1942 he was replaced by Max Kojetinsky from the Viennese Opera. In various periods, the orchestra numbered 32-45 musicians, and its work was supported by the Philharmonischer Verein (Philharmonic Society) established on 10 September 1941 on the initiative and under the chairmanship of the City Mayor Franz Jakob (National Archives in Torun [NAT], Archives of the City of Torun [ACT] 1939-1945, ref. 735, 830, 831; NAT, The Philharmonic Society in Toruń 1941-1944, ref. 1-2; Bundesarchiv Berlin [BB], R 56 - II/91; Thorner Freiheit (29.02.1940), 51, 4; (26.03.1940), 71, 4; (6/7.04.1940), 81, 3; (18.10.1940), 246, 3; (25.06.1942), 147, 4; (4/5.07.1942), 155, 3; Grochowina, 2013, pp. 223-224). It is worth noting that in November 1941, Kapellmeister Rudolf Bub created the Torun String Quartet (Thorner Streichquartett), which - as reported in the press - was the first of its kind in the Danzig-West Prussia Province (Thorner Freiheit (2.02.1942), 27, 3; (7/8.03.1942), 56, 3; (21/22.03.1942), 68, 3). The Bydgoszcz City Orchestra, under the direction of Walter Schumacher, inaugurated its first concert season on November 4, 1940, and on February 27, 1942 the Bydgoszcz String Quartet (Bromberger Streichquartett) gave its first concert (Der Danziger Vorposten (5.02.1940), 35, 5; (7.11.1940), 307, 5; Deutsche Rundschau (26/27.10.1940), 253, 5; (2/3.11.1940), 259, 6; (6.11.1940), 262, 10; (27.02.1942), $49,5)$. In autumn 1943, an orchestra under the baton of the city music director Otto Färber was founded to meet the needs of the municipal theater in Grudziądz. It numbered about thirty musicians and also played concerts for 
city residents (BB, R 56 - II/38; Der Danziger Vorposten (19.11.1943), 319, 6). Another symphonic orchestra functioned in Gdynia under the baton of Max Lille, a Kapellmeister arrived from Hamburg (Deutsche Rundschau (12.06.1940), 136, 6).

Musical culture was shaped both by musical professionals as well as activities of amateurs, including the spreading amateur choral movement, particularly developed in Bydgoszcz. In this city, the Männergesangverein Liedertafel male choir - which in 1942 solemnly celebrated the centenary of its establishment - continued its operations under the direction of Walter Zacharias. At the beginning of November 1940, the Bromberger Chorgemeinschaft (Bydgoszcz Choir Society), chaired by Arthur Sonnenberg, was formed. The director of the local music school Georg Jaedeke led the Bromberger Bachverein (Bydgoszcz Bach Society) Choir. In January 1940, at the initiative of the mayor of the city of Grudziądz, Bruno Keller, and under the direction of Meißner, the Graudenzer Chorgemeinschaft (Grudziądz Choir Association) was established as a continuation of the 19th-century Liedertafel of Grudziądz. In June 1940, a choir was formed in Gdynia under the baton of the director of the municipal symphony orchestra, Max Lille. In October 1940, the choirs in Nowów (under the direction of Melchior) and in Torun - led by Albert Schulz - started their activities, the latter operating under the name Chorgemeinschaft Thorn (Torun Choral Association). In November 1942, Männerchor Neustadt - Male Choir of Wejherowo - was created (Deutsche Rundschau (26.03.1940), 71, 5; (12.06.1940), 136, 6; (27/28.07.1940), 175, 9-10; (11.10.1940), 240, 6; (12/13.10.1940), 241, 7-8; (15.10.1940), 243, 7; (2/3.11.1940), 259, 6; (20.11.1941), 274, 5; (25.11.1941), 278, 5; (23.09.1942), 225, 2; (8.10.1942), 238, 5; (30.11.1942), 283, 5; (18.03.1943), 65, 3; Der Danziger Vorposten (18.01.1941), 17, 5; (8.09.1942), 310, 4; Thorner Freiheit (28/29.09.1940), 229, 3; (3.10.1940), 233, 3; (30/31.05.1942), 125, 3; (8/9.08.1942), $185,3)$.

Music, used by the Nazis as a tool to stimulate appropriate emotions and induce specific behaviors, was present in the public space in a wide range of forms and formats, including symphonic and chamber concerts, and solo and choir performances.

Most often performed were the works of leading German representatives of the Baroque: Johann Sebastian Bach and Georg Händel, pieces by the Viennese classics: Ludwig van Beethoven, Joseph Haydn and Wolfgang Amadeus Mozart, as well as those of Austrian and German Romantics and Neo-Romantics: Johannes Brahms, Anton Bruckner, Robert Schumann, Richard Strauss, Richard Wagner. 
During guest performances, music lovers could get acquainted with the work of composers and pianists particularly appreciated by the Third Reich, such as: Ottmar Gerster, Eduard Künneke, Gottfried Müller, Max Trapp, Hermann Unger, Erik Then-Berg, and Walter Gieseking (Grochowina, 2013, pp. 233-236).

All German cultural institutions, including libraries, museums and theaters, were harnessed into spreading propaganda message among the citizens. Already from the first days of September 1939, local occupant authorities undertook intense efforts to re-start the operations of institutions of this type built on the foundations of confiscated property of their Polish predecessors. On December 18,1939 , the German City Library (Stadtbücherei) in Bydgoszcz opened its doors at General von Kluge Platz 24 (Old Market Square 24). Data from March 1941 indicate that the library had about 1160 readers who borrowed 22,488 books mainly novels, biographies, historical books and works on politics, geography and nature. On May 19, 1941 at Adolf-Hitler-Str. 81 (Gdańska 81) the first branch locations of the City Library in Bydgoszcz was opened; the next one began operating mid-January 1942 at Schleinitzstr. 23 (Chrobrego Street 23) (Deutsche Rundschau (16/17.12.1939), 287, 3, 12; (19.05.1941), 116, 5; (20.05.1941), 117, 5; (10/11.01.1942), 8, 6). In Toruń, the German Municipal Library officially opened on February 15, 1940 in the building of the pre-war Municipal Library at Wysoka Street 12 (Hohegasse 12); its director was Dr. Otto Freymuth (Zakrzewski, 1999, pp. 93-118). The Library collection numbered about 180,000 volumes, and included publications confiscated from other libraries in Toruń, including the ones from the Redemptorist monastery. Ultimately, the Torun Municipal Library was intended to become a scientific library, gathering primarily literature focusing on the former Prussian province. Another library facility was opened in Torun on April 19, 1941 in the building at Bäckergasse 35/37 (Piekary Street 35/37), in the so-called Caesar's Arch. It was a Volksbücherei, or public library, and its collection, originally numbering about four thousand volumes, consisted mainly of books of a popular nature, intended for a mass audience. However, at the start of 1944, the library had already more than ten thousand volumes in its collection. According to data from June 1942, the library could boast 1,434 readers. On November 18, 1941, a Musikbücherei - Music Library - started to operate on the Torun Public Library premises. At the beginning of 1944, it had almost 1,400 publications, including mainly sheet music, which were used primarily by teachers and students of the Torun music school (NAT, ACT 1939-1945, ref. 735; ref. 779; Thorner Freiheit (29/30.03.1941), 75, 3; (16.04.1941), 89, 3; (21.04.1941), 93, 3; (25.06.1941), 147, 4; (8.10.1941), 237, 3; (18.11.1941), 272, 3; (7/8.02.1942), 
32, 3; Niedzielska, 2006, pp.671-674). The library network was systematically expanded and in the summer of 1940, city libraries were opened in Starogard and Tczew, in November 1940 followed by libraries in, inter alia, Chojnice, Czersk, Gniew, Kartuzy, Kościerzyna, Pelplin, Puck, and Wejherowo (Deutsche Rundschau (2/3.11.1940), 259, 10).

In the array of German cultural institutions, an equally important place was held by museums. The Nazi policy of artifact collection was based on destruction of all museum objects having a "Polish character" and preservation of those that allegedly proved the German character of the formerly Polish territories incorporated into the Third Reich. In the Danzig-West Prussia Province, one of the most important museum facilities was the City Museum (Städtisches Museum) in Toruń, with its premises in the Town Hall itself. The position of its director was occupied by Dr. Adolf Schwammberger from Fürth, who simultaneously was also the head of the city's Cultural Office (Kulturamt) (NAT, ACT 1939-1945, ref. 735; ref. 837). On December 1, 1940, the Town Museum in Grudziądz was opened; as its director served Doctor of Philosophy, art historian and folklorist Hans Bernhard Meyer (Deutsche Rundschau (3.12.1940), 285, 10; Thorner Freiheit (3.12.1940), 285, 5; Meyer, 1969, pp. 123-127; Boguwolski, 1999, pp.9-38; Wajler, 2004, pp. 23-24; Sziling, 2012). The City Museum in Bydgoszcz operated under the direction of Dr. Konrad Kothe, and had no permanent premises. Its exhibitions were held mainly in large halls of local schools, and the collections were stored in, among others, the pre-war Catholic House near the Parish Church and in the former pawnshop at Pocztowa Street (Löwenstrasse) (Deutsche Rundschau (13/14.09.1941), 216, 5-6; (3.02.1943), 28, 4; (13/14.02.1943), 37, 5; (15.02.1943), 38, 6; (20/21.02.1943), 43, 4; (20/21.03.1943), 67, 5; Biegański, 2004, p. 413). Museum exhibitions focused primarily on regional history, and the presented artifacts were selected to testify to the supposedly German cultural heritage of the Polish territories incorporated into the Third Reich, and thus to justify the "eternal" right of the German nation to these areas. The titles of the prepared exhibitions spoke for themselves, for example: Thorn - eine Stadt deutschen Geistes (Torun - a City of the German Spirit) - exhibition presented in the Torun Town Hall from December 8, 1940 to January 30, 1941; Deutsche Kunst im Braheland (German Art in the Brda River Country) - exhibition opened on July 19, 1941 in Bydgoszcz in the building of the civilian casino, and made available to visitors for two weeks (Deutsche Rundschau (21.07.1941), 169, 5; (22.07.1941), 170, 5; (25.07.1941), 173, 5; (28.07.1941), 175, 5; (5.08.1941), 182, 5; Thorner Freiheit (11.12.1940), 292, 3; Niedzielska, 2006, p. 669; Birecki, 2011, pp. 93-94; 
Okupowany Toruń w obiektywie..., pp. 118, 288-289). On top of regional history, also wartime successes of German troops and the power of the German armed forces were favoured topics presented at various exhibitions. Two large exhibitions of this type were organized in Torun. At the exhibition titled Wehrmacht. Sonderschau (Wehrmacht. A Special Exhibition), open from February 15 to February 25, 1941, and hosted in the west wing of the Torun Town Hall visitors could familiarize themselves with achievements of the German armed forces (Thorner Freiheit (28.02.1941), 50, 3; (21.12.1943), 300, 3; (22.12.1943), 301 , 4, 6; (4.01.1944), 2, 3; Birecki, 2011, s. 91-92; Okupowany Toruń w obiektywie..., pp. 119, 128-131, 289, 294-297). On December 20, 1943, an exhibition titled Unser Heer (Our Army) was opened - it achieved a record attendance, as by January 2, 1944 , it was visited by 36,945 people. Among the presented objects were portraits and photographs of military commanders, various types of weapons, military uniforms, and a horse model in full military gear.

Theater, also incorporated by the Nazis into their kit of propaganda tools, was to be an institution available to the widest possible audience. Promotion of theater among the public was accompanied by a wide-reaching advertisement campaign. Readers were kept up to date with theatrical repertoire thanks to newspapers, publishing this information among ads usually placed on the last pages. In addition, longer texts presented profiles of artists from individual theaters, as well as reviews of theater premieres. In the Reich Province of DanzigWest Prussia, permanent German theater stages were established in Bydgoszcz, Grudziądz and Torun. The first theater to start operating was the one in Bydgoszcz, headed by Heinrich Voigt. On October 6, 1940, the Main Stage (Grosses Haus) at Theaterplatz (Plac Teatralny) was opened, with almost 730 available seats in the audience. From the beginning of the 1942/1943 season, the Bydgoszcz theater had at its disposal also another, smaller stage (Kleines Haus) for 450 seats, at the intersection of Felix-Dahn-Strasse (Aleje Mickiewicza) and Adolf Hitler Strasse (Gdańska Street), where the lighter repertoire was played. Together with the city orchestra, both stages formed a single organizational unit under the name Städtische Bühnen Bromberg (Bydgoszcz City Stages) (BB, R 55/20334; Der Danziger Vorposten (4.11.1940), 304, 6; (4.08.1942), 214, 4; Deutsche Rundschau (25.09.1940), 226, 5; (5/6.10.1940), 235, 13-14; (7.10.1940), 236, 7; (11.07.1941), 161, 5; (14/15.02.1942), 38, 6; (1/2.08.1942), 180, 5; (20.08.1942), 196, 4; (11.09.1942), 215, 4; (12.09.1942), 216, 5-6; (14.09.1942), 217, 5; Drewniak, 1978, pp. 56-57; Drewniak, 2011, p. 41). Another permanent German theater in the Danzig-West Prussia Province opened on March 28, 1942 in Torun - before that, 
the theater building had been reconstructed and refurbished. At the beginning of October 1943, the Torun theater received a second, smaller stage - so-called Burggarten - previously used by Deutsche Bühne Torun in the interwar period. The function of manager of the Torun theater was held, in chronological order, by: Hans Fiala from Gubin (Lower Lusatia, Brandenburg), Theodor Anton Modes (from July 1, 1942) and Horst Platen (from July 1, 1943) (NAT, ACT 1939-1945, ref. 819; Der Danziger Vorposten (9.07.1942), 188, 3; (19.07.1942), 198, 4; (22.08.1942), 232, 3; Thorner Freiheit (11/12.10.1941), 240, 3; (14.10.1941), 242, 3; (23.10.1941), 250, 3; (28.10.1941), 254, 3; (30.06.1942), 151, 4; (14.07.1942), 163,$4 ;$ (Ostern 1943), 97,3; (1.07.1943), 152,3). The third German theater in the Province of Danzig-West Prussia opened on September 9, 1943 in Grudziądz, and its premises were located in the building of the so-called House of the German National Community (Haus der Deutschen Volksgemeinschaft), which boasted a hall with seven hundred seats. As a director of this institution was appointed Karl Kliewer, formerly the main director of the State Theater in Gdańsk (Deutsche Rundschau (1.11.1940), 258, 6; Der Danziger Vorposten (22.08.1943), 230, 3; (11.09.1943), 250, 3; Thorner Freiheit (29.05.1942), 124, 2; Drewniak, 1978, pp. 58-59; Drewniak, 2011, p. 41). The directors and managers of the aforementioned theaters were obliged to follow strictly defined repertoire policies, and all planned repertoire had to be accepted by Reichsdramaturg Rainer Schlösser. It is not surprising, therefore, that the repertoire played in theaters operating in the Danzig-West Prussia Province did not differ significantly from what was presented on theatrical stages in the so-called Old Reich. It should also be noted that in line with the trend popular in the Third Reich, typical drama theater activity was combined with opera and operetta under one roof. The dramatic repertoire included mainly plays by German classics and romantics, such as: Heinrich von Kleist, Johann Wolfgang Goethe, and Friedrich Schiller. Works of the leader of the Enlightenment age theater restoration movement and propagator of the idea of national drama, Gotthold Ephraim Lessing, were often included in theatrical repertoires as well. Among contemporary German playwrights, the most prominent and popular of them was Gerhart Hauptmann; but also plays by Max Halbe, Paul Helwig, Leo Lenz (full name: Leo Lenz-Schwanzar), Walter Erich Schäfer, and Hans Schweikart were present on theater stages. The repertoire policy also allowed for comedic works of such authors as Maximilian Böttcher, Curt Goetz, August Hinrichs, Friedrich Michael, Ludwig Thoma and Heinrich Zerkaulen to be shown. Works of foreign authors were present to a much lesser extent on the "allowed repertoire" list, what was primarily determined by political considera- 
tions (Grochowina, 2013, pp. 173-184). The opera repertoire was dominated by works of the Viennese classics, Ludwig van Beethoven and Wolfgang Amadeus Mozart. Quite popular were also operatic works by Carl Maria von Weber, Albert Lortzing, Eugen d'Albert, Friedrich von Flotow, Engelbert Humperdinck, Otto Nicolai. Monumental operas and musical dramas of Richard Wagner were put on stage with great flourish, and among the living composers the greatest popularity was enjoyed by the works of Richard Strauss. Italian opera masters Giuseppe Verdi and Giacomo Puccini were representatives of foreign opera on German stages. The operetta canon was made up primarily of works by the master of Viennese operetta, Johann Strauss (Jr). Among the leading operetta composers of the Third Reich, the most frequently shown were the works of: Walter Kollo (real name: Walter Kollodzieyski), Eduard Künneke, and Fred Raymond (true name: Raymond Friedrich von Vesely). The works of Austrian composers Nico Dostal and Ralph Benatzky were pretty popular, and operettas by Hungarian composer Ferenc Lehár were played on theater stages quite often as well (Grochowina, 2013, pp. 184-193).

In addition to "traditional" theatrical scenes also variété revue theaters (Bydgoszcz, Toruń), puppet theaters (Bydgoszcz, Toruń) and a touring theater Landesbühne Reichsgau Danzig-Westpreussen (National Stage of the DanzigWest Prussia Province) operated in the Reich Province of Danzig-West Prussia (Grochowina, 2013, pp. 164, 165-166).

The sketch of German cultural life in the Reich Province of Danzig-West Prussia presented in this paper allows to formulate some general conclusions on the subject of cultural policy pursued by the occupant, which was undoubtedly an important component of the broader nationalist policy. In occupied Poland, including in the Reichsgau Danzig-Westpreussen, the starting point to implementation of the Nazi cultural policy was the destruction of local intellectual elites and cultural heritage of Poles, which was intended to lead to effective dissolution of the nation. In creating their cultural policy, the Nazis were guided primarily by pure pragmatism. Culture was deprived of autonomy, subjected to ideologization and harnessed in the service of a totalitarian state, with the intended recipient of cultural products being exclusively the German population. State and party institutions extended their influence to all domains of cultural life, and no cultural activity was possible without their approval. Independent culture was completely eliminated from public life, and its creators found themselves in bizarre circumstances, as they were deprived of the foundational attribute of their profession, i.e., creative freedom, and subjected to strict administra- 
tive and ideological supervision. Only modern cultural products meeting the expectations of the National Socialist authorities and promoting the meticulously selected values of ancient German cultural heritage - interpreted of course from the current ideological perspective - were allowed to enter into public circulation. Censorship protected citizens against dissemination of any works not in line with the national-socialist outlook. Cultural products, used as propaganda tools to influence the society had to be highly communicative on a mass scale; they were distinguished by sensualism and intended to appeal to emotions of the audience. Ideological persuasion exerted through the means of culture was intended to aid in creation of "a New Man" who would implement the Nazi vision of the future without any moral inhibitions. Culture as an immanent component of propaganda was put to work in the service of a campaign of hatred and racial contempt towards Poles, which went hand in hand with strengthening the spirit of community and sense of racial superiority among Germans. Furthermore, cultural products were used to allegedly prove the "eternally German character" of the annexed Polish territories.

\section{REFERENCES:}

Biały, L. (1987). Izba Kultury Rzeszy w systemie propagandy hitlerowskiej. Studia nad Faszyzmem i Zbrodniami Hitlerowskimi, 12, 241-259.

Biegański, Z. (2004). Walka z kulturą polską. In: M. Biskup (ed.), Historia Bydgoszczy. Vol II. Part II 1939-1945 (p. 413). Bydgoszcz: Bydgoskie Towarzystwo Naukowe.

Birecki, P. (2011). Sztuka w Toruniu w okresie okupacji hitlerowskiej 1939-1945. Toruń: Wydawnictwo Adam Marszałek.

Boguwolski, R. (1999). Das Museum zu Graudenz und ein Beispiel seiner Tätigkeit - ein Streifzug durch die 115 jährige Geschichte des Museums. Beiträge zur Geschichte Westpreussens, 16, 9-38.

Bojarska, B. (1972). Eksterminacja inteligencji polskiej na Pomorzu Gdańskim (wrzesieńgrudzień 1939). Poznań: Instytut Zachodni.

Dahm, V. (1986). Anfänge und Ideologie der Reichskulturkammer. Vierteljahrshefte für Zeitgeschichte, 34(1), 53-84.

Diewerge, W. (1940). Der neue Reichsgau Danzig-Westpreussen. Berlin: Junker \& Dünnhaupt Verlag.

Drewniak, B. (1969). Kultura w cieniu swastyki. Poznań: Wydawnictwo Poznańskie.

Drewniak, B. (1978). Organizacja niemieckiego życia teatralnego na obszarach Polski wcielonych do Rzeszy w latach II wojny światowej. Przeglad Zachodni, 34(4), 55-65.

Drewniak, B. (2011). Teatr i film Trzeciej Rzeszy w systemie hitlerowskiej propagandy. Gdańsk: Wydawnictwo słowo/obraz terytoria. 
Grochowina, S. (2013). Polityka kulturalna niemieckich władz okupacyjnych w Okregu Rzeszy Gdańsk-Prusy Zachodnie, w Okregu Rzeszy Kraj Warty i w Rejencji Katowickiej w latach 1939-1945. Toruń: Fundacja Generał Elżbiety Zawackiej.

Grochowina, S. \& Kącka, K. (2014). Foundations of Nazi Cultural Policy and Institutions Responsible for Its Implementation in the Period 1933-1939. Kultura i Edukacja, 6, 173-192. DOI: 10.15804/kie.2014.06.10.

Janowicz, Z. (1951). Ustrój administracyjny ziem polskich wcielonych do Rzeszy Niemieckiej 1939-1945. Tzw. Okręgi Kraju Warty i Gdańska-Prus Zachodnich. Poznań: Instytut Zachodni.

Jastrzębski, W., \& Sziling, J. (1979). Okupacja hitlerowska na Pomorzu Gdańskim w latach 1939-1945. Gdańsk: Wydawnictwo Morskie.

Madajczyk, Cz. (1970). Polityka III Rzeszy w okupowanej Polsce. Vol. I. Warszawa: Państwowe Wydawnictwo Naukowe.

Meyer, H.B. (1969). Graudenz und sein Stadtmuseum. Westpreussen Jahrbuch, 19, 123-127.

Niedzielska, M. (2006). Organizacja niemieckiego życia kulturalnego w latach 1939-1945. In: M. Biskup (ed.), Historia Torunia. Vol III, part II: W czasach Polski Odrodzonej i okupacji niemieckiej (1920-1945) (pp. 659-695). Toruń: Wydawnictwo Towarzystwa Naukowego w Toruniu.

Okupowany Toruń w obiektywie Kurta Grimma. Niemiecka fotografia propagandowa ze zbiorów Muzeum Okręgowego w Toruniu (2018). [Prepared for Publication by S. Grochowina \& I. Markowska]. Toruń: Muzeum Okręgowe w Toruniu.

Orłowski, H. (1979). Literatura w III Rzeszy. Poznań: Wydawnictwo Poznańskie.

Pospieszalski, K.M. (1946). Polska pod niemieckim prawem 1939-1945 (Ziemie Zachodnie). Poznań: Instytut Zachodni.

Program narodowościowy Rassenpolitischen-Amtu z 1939 roku na ziemiach polskich [1939 Racial and Ethnic Program of the Office of Racial Policy (RassenpolitischenAmt) in the Polish Territories] (1948). Biuletyn Głównej Komisji Badania Zbrodni Niemieckich $w$ Polsce, 4, 135-171.

Schlecht, H., \& Riecke, H. (eds.). (1939). Dichter auf den Schlachtfeldern in Polen. Leipzig-Berlin.

Steyer, D. (1967). Eksterminacja ludności polskiej na Pomorzu Gdańskim w latach 1939-1945. Gdynia: Wydawnictwo Morskie.

Sziling, J. (1989). Jesień 1939. Dokumentacja pierwszych miesięcy okupacji niemieckiej na Pomorzu Gdańskim. Toruń: Toruńskie Towarzystwo Kultury.

Sziling, J. (2012). Germanizacja. In: R. Sudziński (ed.), Historia Grudziądza 1920-1945. Vol. II (pp. 225-253). Grudziądz: Urząd Miejski w Grudziądzu.

Vorläufiger Organisationsplan (1940). Erziehung, Unterricht, Kultur und Gemeinschaftspflege. Amtliches Schulblatt für den Reichsgau Danzig Westpreussen, 3 (1.03.1940), 29-30.

Wajler, A. (2004). Muzeum Miejskie w latach 1940-1945. In: A. Wajler (ed.), 120 lat muzeum w Grudziądzu (pp. 19-24). Grudziądz: Muzeum. 
Wardzyńska, M. (2009). Był rok 1939. Operacja niemieckiej policji bezpieczeństwa $w$ Polsce. Intelligenzaktion. Warszawa: Instytut Pamięci Narodowej. Komisja Ścigania Zbrodni przeciwko Narodowi Polskiemu.

Zakrzewski, T. (1999). Życie i działalność kulturalna Ottona Freymutha w okupowanym Toruniu (1940-1944). Zapiski Historyczne, 64(2), 93-118.

\section{Press:}

Der Danziger Vorposten: (23.10.1939), 251; (24.10.1939), 252; (25.10.1939), 253; (20.11.1939), 279; (5.02.1940), 35; (4.11.1940), 304; (7.11.1940), 307; (18.01.1941), 17; (18.01.1942), 17; (9.07.1942), 188; (19.07.1942), 198; (4.08.1942), 214; (22.08.1942), 232; (8.09.1942), 310; (22.08.1943), 230; (11.09.1943), 250; (21.09.1943), 260; (22.09.1943), 261; (19.11.1943), 319.

Deutsche Rundschau: (26.10.1939), 242; (16/17.12.1939), 287; (26.03.1940), 71; (12.06.1940), 136; (27/28.07.1940), 175; (25.09.1940), 226; (5/6.10.1940), 235; (7.10.1940), 236; (11.10.1940), 240; (12/13.10.1940), 241; (15.10.1940), 243; (26/27.10.1940), 253; (1.11.1940), 258; (2/3.11.1940), 259; (6.11.1940), 262; (3.12.1940), 285; (13.05.1941), 111; (19.05.1941), 116; (20.05.1941), 117; (11.07.1941), 161; (21.07.1941), 169; (22.07.1941), 170; (25.07.1941), 173; (28.07.1941), 175; (5.08.1941), 182; (13/14.09.1941), 216; (20.11.1941), 274; (25.11.1941), 278; (10/11.01.1942), 8; (14/15.02.1942), 38; (27.02.1942), 49; (21.05.1942), 119; (1.06.1942), 127; (1/2.08.1942), 180; (20.08.1942), 196; (11.09.1942), 215; (12.09.1942), 216; (14.09.1942), 217; (23.09.1942), 225; (8.10.1942), 238; (30.11.1942), 283; (3.02.1943), 28; (13/14.02.1943), 37; (15.02.1943), 38; (20/21.02.1943), 43; (18.03.1943), 65; (20/21.03.1943), 67.

Thorner Freiheit: (23.10.1939), 29; (29.02.1940), 51; (26.03.1940), 71; (6/7.04.1940), 81; (16.08.1940), 192; (17/18.08.1940), 193; (19.08.1940), 194; (14/15.09.1940), 217; (17.09.1940), 219; (28/29.09.1940), 229; (3.10.1940), 233; (18.10.1940), 246; (3.12.1940), 285; (11.12.1940), 292; (18.02.1941), 41; (28.02.1941), 50; (29/30.03.1941), 75; (16.04.1941), 89; (21.04.1941), 93; (25.06.1941), 147; (8.10.1941), 237; (11/12.10.1941), 240; (14.10.1941), 242; (23.10.1941), 250; (28.10.1941), 254; (18.11.1941), 272; (5.01.1942), 3; (20.01.1942), 16; (2.02.1942), 27; (7/8.02.1942), 32; (7/8.03.1942), 56; (21/22.03.1942), 68; (29.05.1942), 124; (30/31.05.1942), 125; (1.06.1942), 126; (25.06.1942), 147; (30.06.1942), 151; (4/5.07.1942), 155; (14.07.1942), 163; (8/9.08.1942), 185; (26.08.1942), 200; (29/30.08.1942), 203; (Ostern 1943), 97; (1.07.1943), 152; (21.12.1943), 300; (22.12.1943), 301; (4.01.1944), 2; (14.01.1944), 11; (17.01.1944), 13.

\section{Archival sources:}

Bundesarchiv Berlin, 55/20334.

Bundesarchiv Berlin, R 55/1395, Note on Establishment of the Organization Kulturwerk Deutsches Ordensland. 
Bundesarchiv Berlin, R 56 - II/38

Bundesarchiv Berlin, R 56 - II/91.

National Archives in Gdańsk, Archives of the City of Gniew 1561-1945, ref. 193, Statutes of the Kulturwerk Deutsches Ordensland Organization of August 13, 1941.

National Archives in Gdańsk, Archives of the City of Gniew 1561-1945, ref. 193, Letter of the Head of the Province Propaganda Office to the President of Gdańsk (Danzig) Borough of September 4, 1941.

National Archives in Gdańsk, Archives of the City of Gniew 1561-1945, ref. 193, Statutes of the Ausstellungsgemeinschaft Danzig-Westpreussen Organization.

National Archives in Gdańsk, Archives of the City of Gniew 1561-1945, ref. 193, Statutes of the Ostdeutscher Dichterkreis Organization [not dated].

National Archives in Gdańsk, Archives of the City of Gniew 1561-1945, ref. 193, Letter of the Propaganda Office of the Danzig-West Prussia Province to the president of the Gdańsk (Danzig) borough of September 5, 1941.

National Archives in Gdańsk, Archives of the City of Starogard Gdański 1634-1945, ref. 139, Letter of the National Plenipotentiary for Culture to the Mayor of Starogard Gdański of December 10, 1941.

National Archives in Torun, Archives of the City of Torun 1939-1945, ref. 727, Letter of A. Goergens to the Torun City Commissar W. Kiessling, of October 7, 1939.

National Archives in Torun, Archives of the City of Torun 1939-1945, ref. 735, 779, $819,830,831,837$.

National Archives in Toruń, Archives of the City of Torun 1939-1945, ref. 762, Der Gauring. Mitteilungsblatt des Gauringes Danzig-Westpreussen der NSDAP, Nummer 4-5/1942, pp. 6-8.

National Archives in Torun, The Philharmonic Society in Toruń 1941-1944, ref. 1-2. 